J. Perinat. Med. 15 (1987) 297

\section{Factors affecting nursery survival of very low birth weight infants}

\author{
Annabel J. Teberg, Satit Hotrakitya, Paul Y. K. Wu, Sze-Ya Yeh, and Toke \\ Hoppenbrouwers
}

Neonatology Division, Departments of Pediatrics, and Obstetrics and Gynecology, University of Southern California Medical School, Los Angeles County-USC Medical Center, California, U.S.A.

\section{Introduction}

Recent improvement in the survival of very low brithweight (VLBW) infants, i.e. with birthweights $\leq 1500 \mathrm{~g}$, has been well documented $[14,15,20]$. The impact of the VLBW infants on neonatal mortality is dependent both upon the incidence of VLBW infants born and upon survival of these infants. While factors related to the incidence of VLBW infants have been related to socioeconomic status, maternal health and pregnancy problems $[1,5,7,21]$, the survival within specific birthweight (BW) categories was found to be related to perinatal care and infant maturity $[4,6,9-12,16,17$, 19].

Despite increasing numbers of Hispanic immigrants there is little information regarding the recent incidence of birth and survival of the VLBW infants among the Hispanics. Los Angeles County-University of Southern California Medical Center, Women's Hospital is a tertiary perinatal center with greater than 16000 deliveries per year. The patient population is $87 \%$ Hispanic, highly mobile, of low socio-economic status with no alternative health care resource. More than half are immigrants who speak no English.

A prospective study from January 1982 in December 1983 was done to determine the incidence and survival rate of the VLBW infants,

\section{Curriculum vitae}

Dr. Annabel J. Teberg obtained her M.D. degree from the University of Minnesota, Minneapolis. She completed her pediatric residency at the $L A C$ USC Medical Center, Los Angeles. Currently she is Professor of Clinical Pediatrics and Family Medicine of the University of Southern California School of

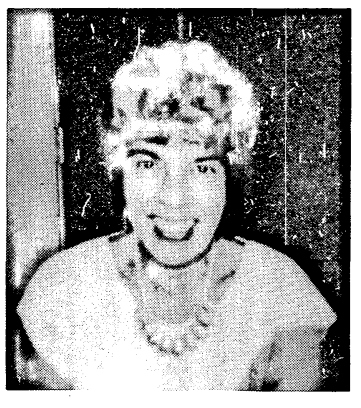
Medicine. She is the Director of the Premature Clinic and High Risk Infant Follow-up Program and Director of the Continuing Care Program of the Neonatalogy Division of the LAC/USC Medical Center. Her main research interest is in the area of growth and development of the high-risk infants.

separated into groups by birth weight and gestational age, and to determine causes of death as well as identify factors influencing outcome of these infants.

\section{Methods}

All inborn live births with BW 500-1500 g, born between January 1, 1982 and December 30,1983 , were included in the study. Survival was determined by discharge from the nursery rather than by the neonatal period of life. Ges- 
tational age (GA) was determined from the first day of the last normal menstrual period (LMP). A clinical estimate of GA by the BALLARD assessment method [2] was used when LMP was unknown or varied by more than two weeks from the estimated GA.

Unless specified, all infants with death due to congenital anomalies were excluded from the analysis. Information was obtained from parent interviews, hospital records, autopsy reports and by ongoing recording of the infant's nursery course. Results were analyzed by chisquare test to compare frequency. Yates correction was used when observed frequency in one cell was less than 10. Student's t-test was used to compare means of normally distributed data.

The primary clinical cause of death was determined according to the criteria of HeINs and BROwn [9], including:

1) Congenital anomalies, when the condition was believed to be incompatible with life or the dominant cause of death regardless of birth weight or other causes.

2) Birth weight $\leq 750$ gm without congenital anomalies, regardless of other causes.

3) Respiratory distress syndrome (RDS), when onset of respiratory distress was within 1 hour of life, required assisted ventilation and had roentgenograms compatible with diagnosis of RDS.

4) Birth asphyxia, when Apgar scores were $\leq 5$ at one and 5 minutes without stabilization.

5) Infection, when the clinical course was compatible with diagnosis and in most cases cultures or autopsy findings documented infection. Infection in our study was expanded to include viral and fungal infections as well as bacterial.

6) Intraventricular (IVH) and intracerebral hemorrhage (ICH), when diagnosed by ultrasonography and/or autopsy and when no other dominant disease such as RDS was present.

7) Others included myocardial infarction, airway obstruction, meconium ileus.

Autopsy cause of death did not include asphyxia as this was most often a clinical diagnosis.

\section{Results}

During the period of the study there were 31234 live births of whom 398 had BW $500-1500 \mathrm{~g}$. These VLBW infants represented $1.3 \%$ of all live births.

Survival (i.e. discharge from nursery) evaluated by BW categories of BW 500-750 g (group 1), $751-1000$ g (group 2), $1001-1250$ g (group 3) and $1251-1500 \mathrm{~g}$ (group 4) is shown on figure 1. Neonatal survival for the group as a whole was $58 \%$ and when anomalies were excluded $61 \%$. After excluding anomalies, significant differences in survival were found between groups 1 and $2(\mathrm{p}<0.001)$, between 2 and $3(\mathrm{p}<$ $0.001)$, and between groups 3 and $4(\mathrm{p}<0.001)$.

Survival by gestational age category is shown in figure 2. Survival was significantly different between infants born $<26$ weeks and 26-27 weeks ( $p<0.001$ ), between $26-27$ and 28-29 weeks $(\mathrm{p}<0.01)$ and between $30-31$ and $32-33$ weeks $(p<0.05)$. After 33 weeks gestation there were no differences in survival when successive GA categories were compared.

When GA and BW were combined, survival increased progressively with increase in $\mathrm{BW}$ and GA categories (table I). When successive BW/ GA categories were compared, survival for infants with $\mathrm{BW}>1000 \mathrm{~g}$ was not significantly affected by GA. For the group with BW $500-750 \mathrm{~g}$ survival was increased if GA was $\geq 28$ weeks ( $\mathrm{p}<0.01$ ). For the $751-1000 \mathrm{~g}$ BW group, survival was increased if GA was $\geq 26$ weeks $(\mathrm{p}<0.05)$.

\subsection{Age at death}

Seventy-nine percent of infants with BW $500-750 \mathrm{~g}$ died within the first 24 hours, while $51 \%$ of the $751-1000 \mathrm{~g}$ group and only $30 \%$ of the $>1000 \mathrm{~g}$ group died during the same period. Although the majority of infants died in the neonatal period, eleven or $6.6 \%$ died after the neonatal period. The 6 post neonatal deaths (PND) with BW $\leq 1000 \mathrm{~g}$ accounted for $5 \%$ of all nursery deaths in this BW category. However, the 5 PND with BW $>1000$ g represented $17 \%$ of the deaths within this BW group. 


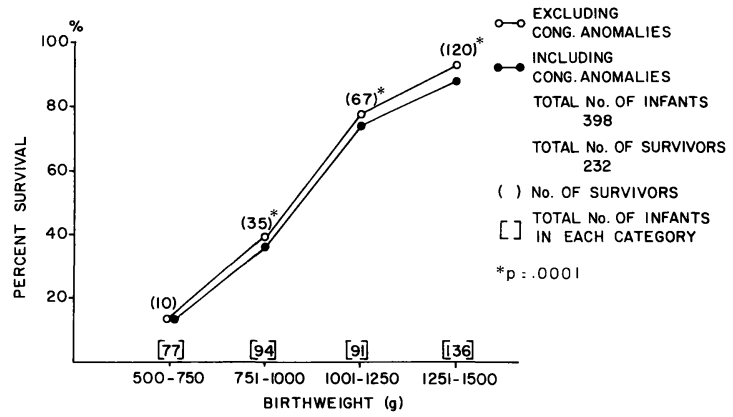

Figure 1. Survival of very low birth weight infants by birth weight categories with and without anomalies. Differences were found in all successive birth weight categories.

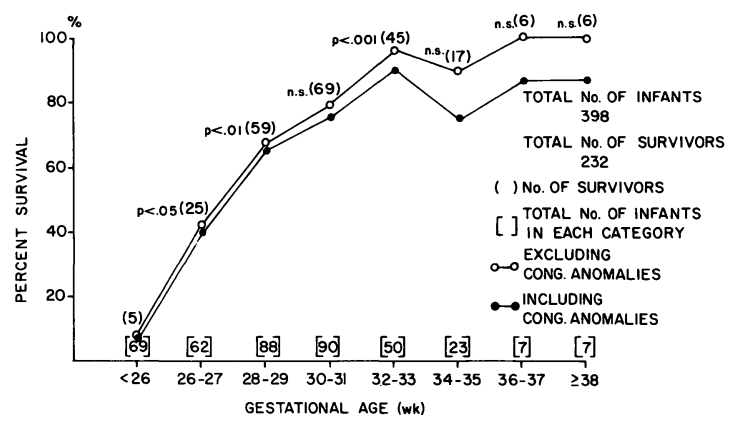

Figure 2. Survival of very low birth weight infants by gestational age categories with and without anomalies. When deaths due to anomalies were removed no differences were found in survival in successive GA categories after 31 weeks gestation.

Table I. Survival by birthweight/gestational age.

\begin{tabular}{lllll}
\hline Gestational age (weeks) & \multicolumn{3}{l}{ Birthweight (grams) } \\
\cline { 2 - 5 } & $\begin{array}{l}500-750 \\
\mathrm{n}=75\end{array}$ & $\begin{array}{l}751-1000 \\
\mathrm{n}=89\end{array}$ & $\begin{array}{l}1000-1250 \\
\mathrm{n}=87\end{array}$ & $\begin{array}{l}1251-1500 \\
\mathrm{n}=129 \\
\%\end{array}$ \\
\hline \multirow{2}{*}{$\%$} & 76 & 7 & & \\
$26-27$ & 8 & $38^{* *}$ & 77 & 67 \\
$28-29$ & $71^{*}$ & 44 & 67 & 100 \\
$30-31$ & 0 & 54 & 81 & 89 \\
$32-33$ & & 67 & 100 & 97 \\
$34-35$ & & 100 & 100 & 100 \\
$36-37$ & & & 100 \\
$38-39$ & & & & 00 \\
\hline
\end{tabular}

* Survival of 26-27 week GA compared with 28-29 week GA significant at p $<0.01$

** Survival of $<26$ week GA compared with $26-27$ week GA significant at $p<0.05$

In the infants who expired beyond the neonatal period, age of death ranged from 29 to 305 days with a median of 57 days. There were no differences in sex or racial distribution or in incidence of SGA when compared to the group as a whole. All of these PND infants had severe cardiopulmonary problems with hypo- and hypertension and/or symptomatic patent ductus arteriosus. They required ventilatory assistance for prolonged periods. Their nursery courses were very complicated. $45 \%$ and necrotizing enterocolitis, $55 \%$ had infection, $64 \%$ had seizures and $82 \%$ required one or more surgical procedures. Autopsy findings showed multiple organ system pathology.

\subsection{Cause of death}

Clinical causes of death were immaturity (BW $<750 \mathrm{~g}$ ) $39 \%$, RDS $17 \%$, asphyxia $15 \%$, anomalies $11 \%, \mathrm{IVH} / \mathrm{ICH} 9 \%$, infection $5 \%$ and other $4 \%$.

Major causes of death by birth weight category are shown in figure 3. Congenital anomalies causing death were found in 18 infants or $4.5 \%$ of the VLBW population. The incidence of lethal anomalies was similar throughout the four BW categories, however as would be expected the anomalies accounted for proportionately fewer deaths among the very tiny infants but were the major causes of death in infants 


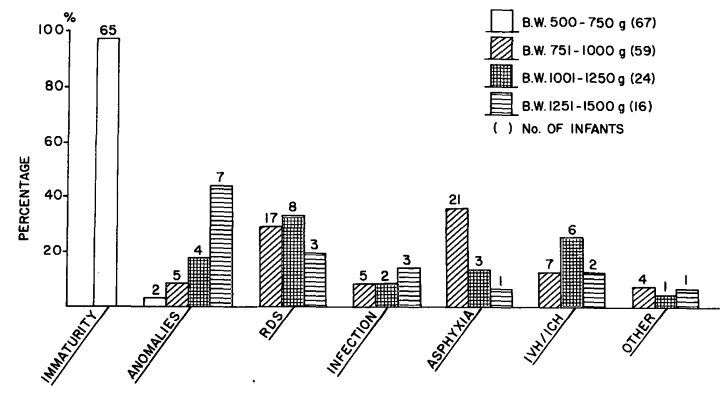

Figure 3. Cause of death by birthweight category. Anomalies were the major cause of death in infants with BW $>1250 \mathrm{~g}$. Asphyxia and respiratory distress syndrome were the major cause of death in infants with BW 751-1000 g.

with BW > $1250 \mathrm{~g}$, accounting for $44 \%$ of all deaths in this weight group. Eleven $(61 \%)$ anomalies affected the central nervous system: 7 infants with anencephaly, 3 with encephalocele, and 1 with hydrocephaly. Three infants had dwarf syndrome $[3,13]$ with asphyxiation, 3 had trisomy 18, and 1 infant had severe gastroschesis. RDS was a major cause of death in all categories of birth weight $>750 \mathrm{~g}$. In infants with BW $751-1000 \mathrm{~g}$, RDS and asphyxia were major causes of death while in the $1001-1250 \mathrm{~g}$ weight group, RDS and IVH were major causes. The proportion of deaths due to infection was similar in all BW categories $>750 \mathrm{~g}$.
Clinical cause of death was evaluated by gestational age category (table II). As expected, immaturity was found to be a major cause of death in infants $<28$ weeks gestation. Congenital anomalies were a major cause of death after 31 weeks gestation. RDS and IVH were among major causes of death between 26-33 weeks gestation. Infection was a major cause of death $>33$ weeks.

\subsection{Autopsy cause of death}

The overall autopsy rate was $68 \%$. The predominant causes of death remained the same (with the exclusion of asphyxia) but incidence varied. In $45 \%$ of infants immaturity was found as cause of death, in $15 \%$ anomalies, in $14 \%$ RDS, in $8 \%$ infection, in $12 \% \mathrm{IVH} / \mathrm{ICH}$ and in $6 \%$ other. Immaturity was found to be a cause of death in $49 \%$ of infants with BW $751-1000 \mathrm{~g}$. IVH/ICH was found with greatest frequency in infants $1001-1250 \mathrm{~g}$. Under 30 weeks gestation immaturity was a major contributor. RDS, infection and congenital anomalies were major causes after 30 weeks.

\subsection{Factors relating to outcome}

The relationship of maternal demographic, medical and pregnancy problems, perinatal and nursery factors to outcome were studies.

Table II. Cause of death by gestational age.

\begin{tabular}{|c|c|c|c|c|c|c|}
\hline \multirow[t]{2}{*}{ Cause of death } & \multicolumn{6}{|c|}{ Gestational age (weeks) } \\
\hline & $\begin{array}{l}<26 \\
(\mathrm{n}=64) \\
\%\end{array}$ & $\begin{array}{l}26-27 \\
(\mathrm{n}=37) \\
\%\end{array}$ & $\begin{array}{l}28-29 \\
(\mathrm{n}=31) \\
\%\end{array}$ & $\begin{array}{l}30-31 \\
(\mathrm{n}=21) \\
\%\end{array}$ & $\begin{array}{l}32-33 \\
(n=5) \\
\%\end{array}$ & $\begin{array}{l}>33 \\
(\mathrm{n}=8) \\
\%\end{array}$ \\
\hline Immaturity & 78 & 27 & 9 & 9 & & \\
\hline Anomalies & 3 & 5 & 7 & 14 & 60 & 75 \\
\hline RDS* & 3 & 30 & 26 & 29 & 20 & \\
\hline Infection & 2 & 8 & 7 & 9 & & 25 \\
\hline Asphyxia & 14 & 14 & 29 & 9 & & \\
\hline $\mathrm{IVH} / \mathrm{ICH}{ }^{* *}$ & & 16 & 19 & 9 & 20 & \\
\hline Other & & & 3 & 20 & & \\
\hline
\end{tabular}

* Respiratory distress syndrome

** Intraventricular/intracerebral hemorrhage 
Medical problems of maternal substance abuse and cigarette smoking were evaluated. Pregnancy history factors evaluated included: lack of prenatal care, obstetrical history of prior stillbirths, neonatal deaths, low birth weight infants or two or more spontaneous abortions. Pregnancy problems evaluated included toxemia, eclampsia, bleeding, placenta previa, abruptio and anemia, ruptured membranes greater than 24 hours. Pregnancy illness evaluated included infections (including amnionitis), hypertension, diabetes, cardiac condition, treated psychiatric problems. Of the listed factors, only one was found to differ in that mothers of non-surviving infants had greater incidence of total lack of prenatal care than mothers of survivors $(p<0.025)$. No other icidence differences were found between survivors and non-survivors (table III).

Differences were found in mean BW and GA (table IV) but not in sex, incidence of small for gestational age (SGA) and multiple birth. More non-surviving infants had low 1 and 5 minute Apgars, required intubation at birth, had an initial nursery $\mathrm{pH}<7.2$, and had RDS than did survivors (table IV).
Since so few infants $<750 \mathrm{~g}$ survived, further comparisons were made on the two weight groups above $750 \mathrm{~g}$, i.e. $751-1000$ and $1001-1500 \mathrm{~g}$. The incidence of pregnancy factors was similar in BW groups and showed no impact on survival in either BW categories (table V). Although the incidence of no prenatal care was higher in non-surviving infants of both BW categories, differences were not satistically significant. Sixty-five or $21 \%$ of the infants with BW $\geq 750 \mathrm{~g}$ were SGA. Demographic factors by BW category are shown in table VI. The incidence of SGA was higher in survivors of both BW categories but differences were not statistically significant. Differences in BW and GA were found in both BW categories with surviving infants being heavier and more mature.

The effect of the method of delivery on outcome was evaluated by comparing outcome of vaginal vertex with non-emergency $\mathrm{C}$-section and with emergency C-section. Since it is the policy in our hospital to deliver VLBW breech infants by $\mathrm{C}$-section, vaginal breech deliveries were excluded from analysis. Non-emergency C-section is defined as a C-Section done for inevitable

Table III. Relation of maternal demographic, health and pregnancy factors to outcome.

\begin{tabular}{llll}
\hline & $\begin{array}{l}\text { Survivors } \\
(\mathrm{n}=232) \\
\%\end{array}$ & $\begin{array}{l}\text { Non-survivors } \\
(\mathrm{n}=148) \\
\%\end{array}$ & $\mathrm{p}$ \\
\hline Maternal age (years) $<18$ & 12 & 11 & $\mathrm{~ns}$ \\
Primigravida & 13 & 9 & $\mathrm{~ns}$ \\
Gravidity $>4$ & 25 & 22 & $\mathrm{~ns}$ \\
Race: & 21 & 18 & $\mathrm{~ns}$ \\
$\quad$ Hispanic & 76 & 76 & $\mathrm{~ns}$ \\
$\quad$ Black & 16 & 14 & $\mathrm{~ns}$ \\
Pregnancy history** & 27 & 18 & $\mathrm{~ns}$ \\
Medical problems*** & 9 & 12 & $\mathrm{~ns}$ \\
Pregnancy problems**** & 44 & 33 & $\mathrm{~ns}$ \\
Pregnancy illness***** & 49 & 34 & $\mathrm{~ns}$ \\
ROM* $>$ 24 hours & 21 & 16 & $\mathrm{~ns}$ \\
No prenatal care & 15 & 25 & $<0.025$ \\
\hline
\end{tabular}

* Rupture of membranes

** No prenatal care, prior stillbirths and neonatal deaths, $\geq$ prior abortions, < BW infants

*** Substance abuse, excess smoking

**** Toxemia, eclampsia, bleeding, anemia, placenta previa

***** Infections, hypertension, diabetes, cardiac conditions 
Table IV. Relation of infant demographic factors status at birth to outcome.

\begin{tabular}{llll}
\hline & $\begin{array}{l}\text { Survivors } \\
(\mathrm{n}=232) \\
\%\end{array}$ & $\begin{array}{l}\text { Non-survivors } \\
(\mathrm{n}=148) \\
\%\end{array}$ & $\mathrm{p}$ \\
\hline Mean BW (grams) & $1211 \pm 222$ & $823 \pm 231$ & $<0.001$ \\
Mean GA (weeks) & $30.4 \pm 2.8$ & $26.3 \pm 2.9$ & $<0.001$ \\
Sex: & 50 & 40 & $\mathrm{~ns}$ \\
$\quad$ Female & 50 & 60 & $\mathrm{~ns}$ \\
$\quad$ Male & 24 & 18 & $\mathrm{~ns}$ \\
SGA & 12 & 16 & $\mathrm{~ns}$ \\
Multiple birth & 39 & 85 & $<0.01$ \\
Apgar 1' $\leq 4$ & 9 & 56 & $<0.001$ \\
Apgar 5 $\leq 4$ & 52 & 75 & $<0.05$ \\
Intubation at birth & 13 & 42 & $<0.01$ \\
Initial pH $<7.2^{*}$ & 67 & 73 & $\mathrm{~ns}$ \\
Asst. ventilation & 47 & 77 & $<0.01$ \\
RDS** & & & \\
\hline
\end{tabular}

* Blood gases done on 208 survivors, 104 non-survivors.

** 33 infants excluded who died shortly after birth.

Table V. Relation of maternal health and pregnancy factors to outcome by birthweight categories.

\begin{tabular}{|c|c|c|c|c|}
\hline & \multicolumn{4}{|c|}{ Birthweight (grams) } \\
\hline & \multicolumn{2}{|l|}{$751-1000$} & \multicolumn{2}{|c|}{$1001-1500$} \\
\hline & $\begin{array}{l}\text { Survivors } \\
(\mathrm{n}=35) \\
\%\end{array}$ & $\begin{array}{l}\text { Non-survivors } \\
(\mathrm{n}=54) \\
\%\end{array}$ & $\begin{array}{l}\text { Survivors } \\
(\mathrm{n}=187) \\
\%\end{array}$ & $\begin{array}{l}\text { Non-survivors } \\
(\mathrm{n}=29) \\
\%\end{array}$ \\
\hline Pregnancy history & 24 & 14 & 28 & 17 \\
\hline Medical problems & 3 & 9 & 10 & 18 \\
\hline Pregnancy problems & 56 & 33 & 40 & 38 \\
\hline Pregnancy illness & 47 & 35 & 36 & 28 \\
\hline $\mathrm{ROM}>24 \mathrm{hr}$ & 15 & 8 & 22 & 14 \\
\hline No prenatal care & 18 & 26 & 14 & 25 \\
\hline
\end{tabular}

Differences were not significant

delivery but prior to evidence of fetal distress. No differences in outcome were found by method of delivery in the larger weight group. In the infants with BW $751-1000 \mathrm{~g}$ non-emergency $\mathrm{C}$-section had more favorable outcome than vaginal delivery $(\mathrm{p}<0.05)$ (figure 4$)$.

When perinatal factors were evaluated by the two weight groups, only the 5 minute low Apgar and low initial $\mathrm{pH}$ were significant in the infants with BW $751-1000 \mathrm{~g}$. In the larger BW infants, low 1 and 5 minute Apgar, immediate intubation for resuscitation, low initial $\mathrm{pH}$ and RDS were found more often in non-surviving infants.

\section{Discussion}

The contribution of the VLBW infant to neonatal mortality is dependent upon the incidence of these births and on the incidence of survival of these infants. The significant impact of social, economic, racial and maternal factors on the incidence of birth of the VLBW infant is well accepted [5, 14, 16]. Less well accepted is the impact of these factors upon the survival of these infants. We have evaluated these factors in our hospital VLBW population to determine their impact on incidence and outcome. The racial background of women delivering at 
Table VI. Relationship between infant demographic and perinatal factors with outcome by birthweight categories.

\begin{tabular}{|c|c|c|c|c|c|c|}
\hline & \multicolumn{6}{|c|}{ Birthweight (grams) } \\
\hline & \multicolumn{3}{|l|}{$751-1000$} & \multicolumn{3}{|l|}{$1001-1500$} \\
\hline & $\begin{array}{l}\text { Survivors } \\
(\mathrm{n}=35) \\
\%\end{array}$ & $\begin{array}{l}\text { Non-survivors } \\
(\mathrm{n}=54) \\
\%\end{array}$ & $\mathrm{p}$ & $\begin{array}{l}\text { Survivors } \\
(\mathrm{n}=187) \\
\%\end{array}$ & $\begin{array}{l}\text { Non-survivors } \\
(\mathrm{n}=29) \\
\%\end{array}$ & $\mathrm{p}$ \\
\hline BW & $987 \pm 76$ & $862 \pm 76$ & $<0.05$ & $1297 \pm 141$ & $1193 \pm 145$ & $<0.01$ \\
\hline GA & $28.6 \pm 2.6$ & $27.1 \pm 2.0$ & $<0.01$ & $31.0 \pm 2.6$ & $29.4 \pm 2.1$ & $<0.01$ \\
\hline Female & 54 & 35 & ns & 49 & $41-$ & ns \\
\hline Male & 46 & 65 & ns & 51 & 59 & ns \\
\hline SGA & 43 & 22 & ns & 20 & 7 & ns \\
\hline Apgar $1^{\prime}<4$ & 57 & 86 & ns & 34 & 69 & $<0.05$ \\
\hline Apgar $5^{\prime}<4$ & 6 & 49 & $<0.01$ & 8 & 24 & $<0.05$ \\
\hline Intubation at birth & 89 & 89 & ns & 43 & 90 & $<0.05$ \\
\hline Initial ph $<7.2$ & 11 & 42 & $<0.05$ & 12 & 31 & $<0.05$ \\
\hline Assist. ventilation & 89 & 91 & ns & 61 & 97 & ns \\
\hline RDS & 66 & $84^{*}$ & ns & 40 & 79 & $<0.05$ \\
\hline
\end{tabular}

* Excluding 5 infants who died shortly after birth.

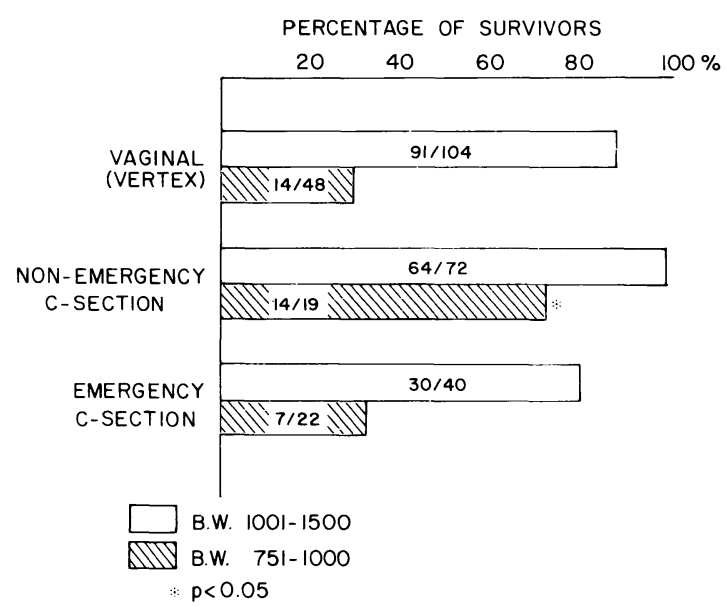

Figure 4. Relation of method of delivery to outcome. Infants with birth weight $\leq 1000 \mathrm{~g}$ delivered by nonemergency $\mathrm{C}$-section survived more often than those delivered vaginally.

LAC/USC Medical Center has changed dramatically over the past 20 years from a low socioeconomic, predominantly black population to a low socioeconomic, predominantly Hispanic population. In addition to low socioeconomic status the hispanic population is largely Spanish speaking and immigrant with few or no community supports. Despite these population differences the incidence of VLBW infants has remained below $1.5 \%$ of all births during the period of population change. Although the VLBW infants constitute a small percentage of total births, they accounted for $72 \%$ of all neonatal deaths during the two year study period.

Nursery survival was not found to be related to socioeconomic, racial, maternal or prenatal factors studied. This is in agreement with the findings of $\mathrm{YU}$ and HollingswORTH in their analysis of data from 55 infants weighing $\leq 1000 \mathrm{~g}$ [22]. Survival of infants with BW $500-1500 \mathrm{~g}$ was directly related to $\mathrm{BW}$ and GA. Maturity as measured by GA was more reliable than $\mathrm{BW}$ in determining outcome in those infants with $\mathrm{BW} \leq 1000 \mathrm{~g}$. The prenatal prediction of $\mathrm{BW}$ in the infant $\leq 1000 \mathrm{~g}$ has been accurate and useful in our center, while the prenatal prediction of maturity is often more difficult and less accurate. In infants with BW $\leq 1000 \mathrm{~g}$, in addition to maturity, survival was determined by their condition at birth as measured by Apgar score. When these infants were delivered by elective $\mathrm{C}$-section without evidence of acidosis or depression they had better survival in our nursery. 
Whereas survival was influenced by weight in all BW categories, a BW of $1000 \mathrm{~g}$ seemed to be a critical weight above which survival was not dependent upon method of delivery. However, gestation continued to influence survival until > 31 weeks. Infants at or less than 26 weeks gestation had a much higher mortality than those above 26 weeks. From the morphological and functional developmental point of view this is to be expected e.g. the lung will not be functional in the human of less than 26 weeks [18]. Condition at birth and need for vigorous ventilatory support were determinants of outcome.

Of particular interest are those infants who expired in the nursery after the neonatal period. With increased capability of ventilatory support, infants who previously died soon after birth from cardiopulmonary problems now survive beyond 28 days of life. Neonatal mortality does not address this group which made up $6.6 \%$ of all the VLBW deaths in our center. HACK et al. [8] also found 14\% of their VLBW infant died in the postneonatal period. Clearly this group of infants needs to be incorporated into the overall evaluated of VLBW infant outcome. The nursery course of these infants tends to be very complicated with multiple organ system involvement. This group, although small, represents a disproportionately high utilization of hospital resources. The severe protracted course with fetal outcome results in immeasurable anxiety, grief and disappointment for families and hospital staff. A decision to discontinue support for an infant where there is no reasonable hope for survival is very difficult for staff and family to make.

In summary, factors other than those in the perinatal and postnatal period do not significantly influence survival of VLBW infants. Gestational age more than birthweight appears to be the limiting factor. Although infants with BW below $1000 \mathrm{~g}$ delivered by elective C-section were found to have better survival in our study; nevertheless, their survival is more dependent on maturity than on birthweight. Condition of the infant at birth, prevention of asphyxia and acidosis, as well as rapid resuscitation and stabilization after birth would reduce mortality in these VLBW infants.

And finally, despite improved survival for smaller and smaller infants only the prevention of early delivery will greatly reduce the excessive morbidity and mortality and the enormous usage of hospital resources represented by this small but significant group of infants.

\section{Summary}

398 infants with birthweight (BW) $500-1500 \mathrm{~g}$ born from January 21982 to December 1983 were studied to determine incidence and survival rate by $\mathrm{BW}$ and gestational age (GA) categories and to determine causes of death and factors influencing mortality. $58 \%$ of the group survived. Factors other than those in the perinatal and postnatal period did not significantly influence survival. Infants with BW below $1000 \mathrm{~g}$ delivered by elective

C-section had better survival than those delivered vaginally. Surival increased progressively with increasing BW and GA categories with GA more than BW being the limiting factor. Eleven $(6.6 \%)$ of the deaths in the very low birth weight infants occurred during the nursery period after 28 days of age. These deaths would not have been addressed in the neonatal mortality.

Keywords: Gestational age, nursery survival, very low birth weight.

\section{Zusammenfassung}

Überlebensrate von Neugeborenen mit extrem niedrigem Geburtsgewicht

Unsere Studie umfaßt 398 Kinder mit einem Geburtsgewicht von $500-1500 \mathrm{~g}$, die im Zeitraum Januar 1982 bis Dezember 1983 geboren wurden. Wir wollten bestimmen, wie das Geburtsgewicht und das Gestationsalter bzw. andere Faktoren die neonatale Mortalität beeinflussen. $58 \%$ des Kollektivs überlebten. Es zeigte sich, $\mathrm{da} B$ in der Neonatalphase die gleichen Risikofaktoren wie in der Perinatal- und Postnatalperiode die Überlebensrate beeinflußten. Kinder mit einem Geburtsgewicht unter $1000 \mathrm{~g}$, die durch primäre Sectio entbunden 
wurden, hatten eine größere Chance als vaginal entbundene Kinder. Mit zunehmendem Geburtsgewicht und Gestationsalter stieg die Überlebensrate, wobei dem Gestationsalter die größere Bedeutung zukam. 11 Todes- fälle $(6.6 \%)$ traten erst nach dem 28 . Lebenstag auf, so daß sie eigentlich nicht mehr mit der neonatalen Mortalität erfaßt würden.

Schlüsselwörter: Extrem niedriges Geburtsgewicht, Gestationsalter, Überlebensrate.

\section{Résumé}

Facteurs affectant la survie en nursérie des enfants de très faible poids de naissance

On a étudié 398 enfants de poids de naissance (P.N.) compris entre 500 et $1500 \mathrm{~g}$, nés entre janvier 1982 et décembre 1983, afin de déterminer, l'incidence et le taux de survie par P.N., les tranches d'âge gestationnel (A. G.), pour déterminer également les causes de mortalité et les facteurs influencant la mortalité.

$58 \%$ du groupe ont survécu. Les autres facteurs que ceux des périodes périnatales et postnatales n'influencent pas significativement la survie. Les enfants de P. N. inférieur à $1000 \mathrm{~g}$ nés par césarienne ont une survie meilleure que ceux nés par voie basse. La survie s'élève progressivement avec l'augmentation du P.N. et des tranches d'A. G., l'A. G. étant le facteur limitant plus que le P.N. Onze $(6,6 \%)$ des morts d'enfants de très faible poids de naissance sont survenues pendant la période de nursing après 28 jours de vie. Ces morts ne devraient pas faire partie de la mortalité néonatale.

Mots-clés: Age gestationnel, enfants de très faible poids de naissance, survie en nurserie.

\section{References}

[1] Abernathy JR, BG Gurnberg, JF Donnelly: Application of discriminant functions in perinatal death and survival. Am J Obstet Gynecol 95 (1966) 860

[2] Ballard JL, K Kazmaier, M Driver: A simplified assessment of gestational age. Pediatr Res 11 (1977) 374

[3] BARNes ND, D Hull, JS Symons: Thoracic dystrophy. Arch Dis Child 44 (1969) 11

[4] Cohen RS, DK Stevenson, N Malachowski, RL ARIAGNO, KJ Kimble, AO Hopper, JD JoHnson, K UELAND, P SUNSHINE: Favorable results of neonatal intensive care for very low-birth weight infants. Pediatrics 69 (1982) 621

[5] DotT AB, AT ForT: The effect of maternal demographic factors in infant mortality rates. Summary of the Louisiana Infant Mortality Study. Part I. Am J Obstet Gynecol 123 (1975) 847

[6] EfFer SB, S Saigal, C RAND, DJS Hunter, B Stoskopf, AC Harper, C NimROD, R Milner: Effect of delivery method on outcomes in the very low-birth weight breech infant: Is the improved survival related to cesarean section or other perinatal care maneuvers? Am J Obstet Gynecol 145 (1983) 123

[7] GoRTMAKER SL: The effect of prenatal care upon the health of the newborn. Am J Public Health 69 (1979) 653

[8] HaCk M, IR Merkatz, PK Jones, a Fanaroff: Changing trends of neonatal and postneonatal deaths in very-low-birth-weight infants. Am J Obstet Gynecol 137 (1980) 797

[9] HeINs HA, CV BRown: Neonatal mortality review: A basis for improving care. Pediatrics 68 (1981) 504
[10] Herschel M, JL KenNedy JR, HL Kayne, M Henry, CL CeTrulo: Survival of infants born at 24 to 28 weeks gestation. Obstet Gynecol 60 (1982) 154

[11] Horwood SP, MH Boyle, GW Torrance, JC SinCLAIR: Mortality and morbidity of 500-1499 gram birth weight infants live-born to residents of defined geographic region before and after neonatal intensive care. Pediatrics 69 (1982) 613

[12] Kessner DM, J Singer, CE Kalk, ER SchleSINGER: Infant death: An analysis by maternal risk and health care. Institute of Medicine, Washington, DC, 1973

[13] Langer LO, JW Spranger, I Greinacher, RC HERDMAN: Thanatophoric dwarfism. Radiology 92 (1969) 285

[14] Lee KS, N Paneth, LM Gartner, Ma Pearlman, L GRUSS: Neonatal mortality: An analysis of the recent improvement in the United States. Am J Public Health 70 (1980) 15

[15] Paneth N, Jl Kiely, S Wallenstein, M Marcus, J PAKTER, M SUSSER: Newborn intensive care and neonatal mortality in low-birth-weight infants. $\mathrm{N}$ Engl J Med 307 (1982) 149

[16] Perkins RP: The neonatal significance of selected perinatal events among infants of low birth weight. Am J Obstet Gynecol 139 (1981) 546

[17] Philip AGS, GA Little, DR Polivy, JF Lucey: Neonatal mortality risk for the eighties: The importance of birth weight/gestational age groups. Pediatrics 68 (1981) 122

[18] ReID L: The embryology of the lung. In: ReucK AVS DE, R PORTER (eds): Development of the lung, p 109. Ciba Foundation Symposium, Boston. Little, Brown, and Co., Boston, MA, 1967 
[19] Ross G: Morality and morbidity in very low birth weight infants. Pediatr Ann 12 (1983) 32

[20] US Bureau of the Census, Statistical Abstract of the United States, 101st edition, (1980) p 61. Washington, DC, 1980

[21] Worthington D, LE Davis, JP Grausg, K SobocINSKI: Factors influencing survival and morbidity with very low birth weight delivery. Obstet Gynecol 62 (1983) 550
[22] Yu VYH, E HollingswORTH: Improving prognosis for infants weighing $1000 \mathrm{~g}$ or less at birth. Arch Dis Child 55 (1979) 422

Received April 20, 1986. Accepted September 10, 1986.

Annabel J. Teberg, M. D.

Women's Hospital, L-919

1240 North Mission Road

Los Angeles, CA 90033, U.S. A. 